\title{
MODIFIKASI PEMBUAT MOL LIMBAH ORGANIK BAHAN PRAKTIKUM DI LABORATORIUM POLITEKNIK PERTANIAN NEGERI PAYAKUMBUH
}

\author{
Linda Tri Maiza ${ }^{1}$, Yubniati ${ }^{2}$, Rio Hermansyah ${ }^{3}$ \\ 1. Budidaya Tanaman Pangan, Politeknik Pertanian Negeri Payakumbuh \\ 2. Jl.Raya Negara Km 7 Tanjung Pati,Limapuluh Kota \\ *Email: lindatrimaiza@gmail.com
}

\begin{abstract}
Local microorganism made in bio activator of making compost and liquid organic fertilizer that can be used for plant cultivation activaties in intitututional environment. All this time, local microorganism maker tool using plastic bucket with lid, produce local MOL is still low, which is charecterized by a foul-smelling aroma of local microorganism, the resulting solution is coarsely precipitated, also not efficient at harvest time. The purpose of this research is to know the performence of the local microorganism maker tool which has been modified. Observation include in term of scent quality, clean liness of solution time efficiency and energy Testing of unmodified local microorganism maker tool and which have been modified by using vegetables and fruit. From the iest result show that the modified local local microorganism maker tols with filter and faucet produce local microorganism better quality, which are indicated by typical scent of local microorganism and cleanliness of solution, its doest'nt cause a problem of time and energy at harvest time, it can be concluded that a modified local microorganism maker tool with filter and faucet at the bottom of the container give better quality of local microorganism.
\end{abstract}

Keywords : local microorganism (MOL), modified local microorganism maker tool, organic material, local microorganism maker tool, MOL Quality.

\section{INTISARI}

Salah satu pemanfaatan limbah organik dari sisa praktikum di lingkungan Politeknik Pertanian Negeri Payakumbuh adalah sebagai bahan pembuatan MOL. MOL dijadikan bioaktivator pembuatan kompos dan pupuk organik cair yang dapat digunakan dalam kegiatan budidaya tanaman di lingkungan institusi. Alat pembuat MOL selama ini memakai ember plastik bertutup, menghasilkan kualitas MOL yang masih rendah, ditandai dengan aroma MOL berbau busuk, larutan yang dihasilkan banyak endapan, serta tidak efisien dalam saat panen. Penelitian ini bertujuan untuk mengetahui kinerja alat pembuat MOL yang sudah dimodifikasi. Pengamatan meliputi dari segi kualitas aroma, kebersihan, efisiensi waktu dan tenaga, serta pengujian kinerja pembuat alat pembuat MOL yang belum dimodifikasi dan sudah di modifikasi dengan memakai bahan sayuran dan buah-buahan. Dari hasil pengujian menunjukkan bahwa alat modifikasi pembuat MOL yang menggunakan saringan dan kran memberi kinerja lebih efisien, hasil kualitas MOL lebih baik, ditandai larutan MOL dengan aroma khas dan penampakan larutannya bersih, tidak menimbulkan kendala saat panen dari segi waktu dan tenaga. Dapat disimpulkan bahwa alat pembuat MOL yang di modifikasi memakai saringan dengan menambahkan kran dibagian dasar wadahnya memberi tingkat kinerja alat lebih baik dengan kualitas MOL lebih baik.

Kata kunci : Mikroorganisme Lokal (MOL), Alat modifikasi MOL, bahan organik, Alat Pembuat MOL, kualitas MOL. 


\section{PENDAHULUAN}

Di Politeknik Pertanian Negeri Payakumbuh pemakaian bahan praktikum lebih banyak berbasis bahan organik nabati baik berupa buah-buahan ataupun tanaman hijauan. Limbah bahan organik tersebut dijadikan bahan baku kompos padat dan dijadikan MOL. MOL bermanfaat sekali untuk bioaktifator pembuatan kompos padat dan pupuk organik cair. Pembuatan MOL pada Jurusan Budidaya Tanaman Pangan pada beberapa Mata Kuliah masih menggunakan alat pembuat MOL berupa ember bertutup yang ditambah selang. Sebagaimana dalam Mulyono (2014) bahwa wadah pembuat MOL dibuatkan lubang bagian tutup dan diberi slang diarahkan ke btol berisi air. Namun tingkat keberhasilan fermentasi MOL saat ini masih rendah ditandai MOL beraroma busuk.

Penelitian ini bertujuan untuk menciptakan alat modifikasi pembuatan MOL yang efektif dan efisien. Sehingga bermanfaat bagi mahasiswa yang melakukan praktikum pembuatan MOL serta memberi nilai tambah terhadap limbah organik bahan praktikum. Hasil MOL juga dapat dimanfaatkan untuk bahan baku praktikum Budidaya Tanaman di lingkungan Politeknik Pertanian.

MOL merupakan mikroorganisme lokal hasil fermentasi dari bahan yang ada di lingkungan sekitar dan mudah didapat (Mulyono, 2015). Menurut Hadisuwito (2012), alat yang digunakan untuk membuat MOL ini berupa tong yang telah dimodifikasi. Palupi (2015) menyampaikan pembuatan MOL dengan menutup rapat wadah menggunakan koran satu lapisan dibawah tutupnya. Juanda ( 2011 ) menyarankan fermentasi pembuatan MOL dalam wadah tertutup rapat dan kuat.

Tujuan pembuatan alat pembuat MOL yang telah dimodifikasi ini untuk mendapatkan alat pembuat MOL yang efiensi dan efektif baik segi kualitas MOL dan kinerja alatnya.

\section{METODE PENELITIAN}

\section{Waktu dan tempat.}

Penelitian dilaksanakan pada bulan Juli s.d. Oktober 2020 berlokasi di Laboratorium Politeknik Negeri Pertanian Payakumbuh. Penelitian ini membandingkan kinerja alat yang dimodifikasi dengan penyaring dan tanpa penyaring. Memakai kontrol alat pembuat MOL yang tidak dimodifikasi. Memakai bahan organik asal buah-buah dan sayuran hijau.

\section{Alat dan Bahan.}

Alat : Ember bertutup volume 55 lt. berjumlah 14 buah, Botol sample 130 buah, Deregen vol 20 lt 6 buah, Gergaji 1 buah, rak ember 4 buah, Baskom plastik besar 6 buah, Talenan 3 buah, Pisau stainles steel 3, Gayung 2 buah, Saringan 3 buah, Corong ukuran sedang 3 buah, Beaker Glass 4 buah, Botol air mineral vol. $600 \mathrm{ml}$ 12 buah.

Bahan-bahan antara lain : Kran 12 buah Slang diameter 0,5 inch 1 gulungan, Lem paralon 3 buah, Air kelapa 120 lt, Limbah buah-buah $120 \mathrm{~kg}$, Limbah dedaunan $120 \mathrm{~kg}$, Gula merah $12 \mathrm{~kg}$, Ijuk 1 karung 50 kg, krekel 1 karung 50 kg.

\section{Prosedur Kerja.}

1. Mempersiapkan Alat yang akan dipakai berupa ember bertutup (kontrol) dirakit dengan memasang slang udara pada bagian tutup

2. Mempersiapkan Alat Pembuat MOL modifikasi dari ember bertutup yang dimodifikasi pada bagian tutup dipasangkan pengaduk, dan kran dibagian bawah luar ember serta menambahkan penyaring organik pada lapisan terbawah berupa ijuk setinggi $5 \mathrm{~cm}$, dan kerekel setinggi $5 \mathrm{~cm}$

3. Mempersiapkan Alat Pembuat MOL modifikasi dari ember bertutup yang dimodifikasi dibagian tutup dipasangkan pengaduk dan kran dibagian bawah ember tanpa penyaring organik

4. Membuat bahan MOL dari air kelapa : bahan organik : gula merah $(1: 1: 1 / 10)$, Gula merah diiris halus dan dicampurkan dengan air kelapa yang sudah ada dalam baskom kemudian diaduk sampai larut

5. Pemotongan bahan organik (sayuran dan buahan) sampai halus

6. Menyusun bahan organik dalam ember kontrol dan ember modifikasi. Menuangkan larutan gula + air kelapa ke atas bahan organik sambil diaduk.

7. Memasang pengaduk pada tutup dan slang aerasi udara disambungkan ke botol berisi air.

8. Dibiarkan selama 15 hari dengan dilakukan 3 hari sekali. 


\section{Pengumpulan data}

Pengamatan dilakukan selama 4 minggu, dengan mengamati aroma MOL, endapan MOL, penghitungan waktu penggunaan alat pada tiap Alat Pembuat MOL ember bertutup tanpa modifikasi dan ember bertutup dengan modifikasi.

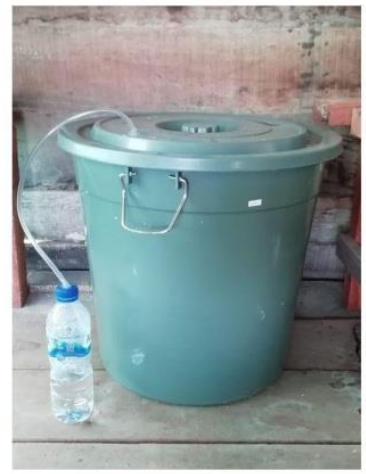

Gambar 1. Ember MOL tanpa modifikasi

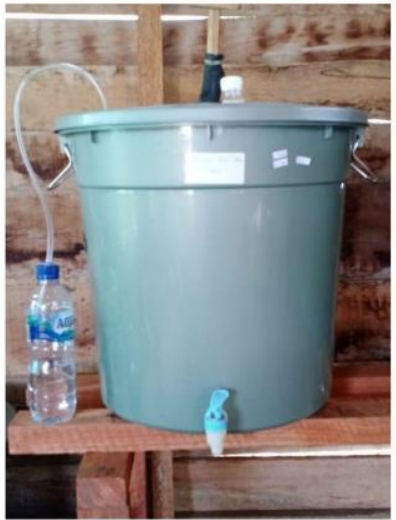

Gambar 2. Ember MOL Modifikasi tampak luar
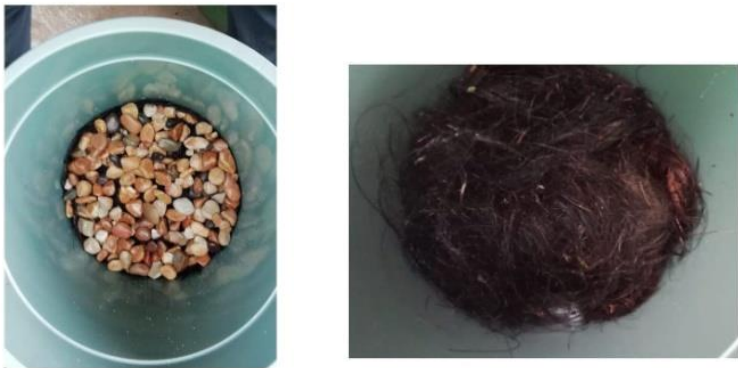

Gambar 3. Ember modifikasi dengan penyaring berupa kerekel dan ijuk tampa dalam

\section{HASIL DAN PEMBAHASAN}

Hasil pengamatan kualitas larutan MOL meliputi bau (aroma), endapan setelah 2 minggu masa fermentasi disajikan dalam Tabel 1.

\section{Tabel 1. Kualitas MOL}

\begin{tabular}{lcl}
\hline Alat MOL & bau(aroma) & kebersihan \\
\hline $\begin{array}{l}\text { Alat Kontrol } \\
\text { sayuran }\end{array}$ & agak busuk & $\begin{array}{l}\text { banyak } \\
\text { endapan }\end{array}$ \\
$\begin{array}{l}\text { Alat kontrol } \\
\text { buah }\end{array}$ & agak busuk & $\begin{array}{l}\text { banyak } \\
\text { endapan } \\
\text { Alat Modifikasi }\end{array}$ \\
$\begin{array}{l}\text { Bersaring sayur } \\
\text { Alat Modifikasi }\end{array}$ & aroma khas & sedikit endapan \\
Tanpa Bersaring & & \\
sayur & & bersih \\
$\begin{array}{l}\text { Alat modifikasi } \\
\text { Bersaring buah } \\
\text { Alat Modifikasi }\end{array}$ & aroma khas & \\
Tanpa saring buah & & sedikit endapan \\
\hline
\end{tabular}

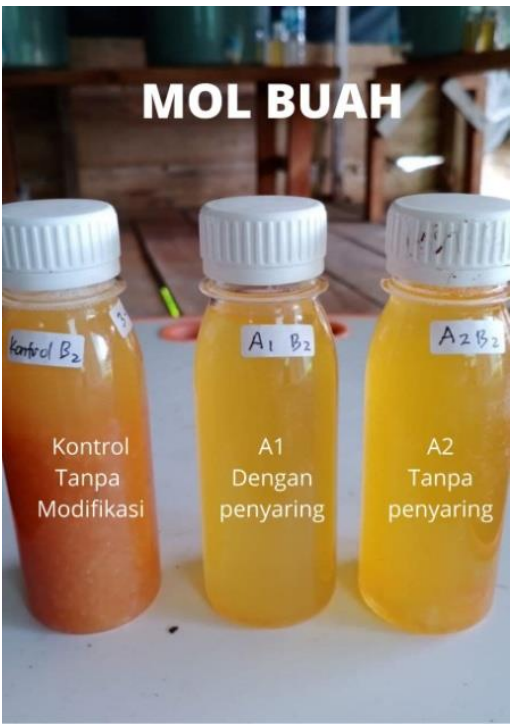

Gambar 3. Penampakan visual endapan MOL Buah pada alat pembuat MOL tanpa modifikasi (Kontrol), alat pembuat MOL dimodifikasi + saringan (A1), dan pada alat pembuat MOL dimodifikasi tanpa saringan (A2) 


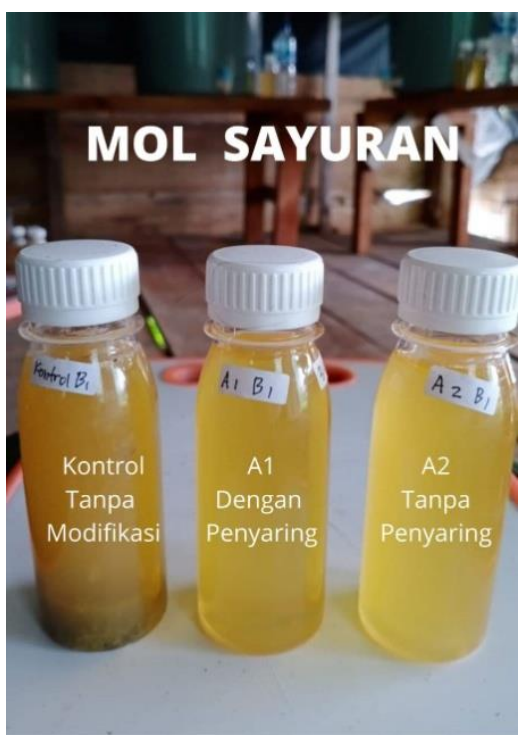

Gambar 4. Penampakan visual endapan MOL sayuran pada alat pembuat MOL tanpa modifikasi (Kontrol), alat pembuat MOL dimodifikasi + saringan (A1), dan pada alat pembuat MOL dimodifikasi tanpa saringan (A2)

Pemakaian alat pembuat MOL modifikasi bersaring berbahan sayur dan alat pembuat MOL modifikasi bersaring buah mampu memberikan kualitas MOL yang baik dibandingkan dengan alat modifikasi tanpa saring dan alat tanpa modifikasi (kontrol). Pengamatan kualitas aroma MOL yang dihasilkan khas buah atau sayur pada alat modifikasi bersaring dibandingkan perlakuan lainya. Sesuai redaksi Trubus (2012), limbah buah aromanya mirip buah yang difermentasikan. Penyaring yang dipasang di dalam ember berupa ijuk dan kerekel, menahan struktur bahan MOL keluar bersama larutan.

Terlihat pada tabel 1. Kualitas MOL Alat biasa sayuran memiliki aroma agak busuk dan banyak endapan, begitu juga alat biasa buah juga memiliki aroma agak busuk dan banyak endapan. Hal ini disebabkan dalam pengadukan MOL, tutup ember harus dibuka sehingga memungkinkan masuknya organisme pembusuk. MOL yang dihasilkan juga memiliki endapan lebih banyak, sehingga harus dilakukan penyaringan di luar. Aroma yang agak busuk menandakan MOL tidak berhasil. Menurut Farida (2009), MOL yang sudah matang ditandai dengan aroma yang tidak menyengat berbau seperti tape.
Pada percobaan ini, alat pembuat MOL modifikasi dengan tambahan saringan memberi hasil lebih baik dikarenakan ember tertutup memiliki pengaduk memungkinkan pengadukan tanpa membuka tutup, membuat proses fermentasi tidak terganggu oleh organisme pembusuk dari luar..

Hasil pengamatan penghitungan efisiensi waktu saat memanen MOL dalam kemasan $100 \mathrm{ml}$ dan di konversi ke kemasan $1000 \mathrm{ml}$, dapat dilihat pada Tabel 2

Tabel. 2 Uji Kinerja efisiensi waktu alat MOL

\begin{tabular}{lcc}
\hline Alat MOL & \multicolumn{2}{c}{ lama panen (detik) } \\
& Per kemasan 100ml & $1000 \mathrm{ml}$ \\
\hline $\begin{array}{l}\text { Alat Biasa } \\
\text { sayuran }\end{array}$ & 32 & 320 \\
$\begin{array}{l}\text { Alat biasa } \\
\text { buah }\end{array}$ & 27 & 270 \\
Alat Modifikasi & 4 & \\
Bersaring sayur & & 40 \\
Alat Modifikasi & 6 & 60 \\
Tanpa Bersaring & & \\
sayur & & \\
Alat modifikasi & 3 & \\
Bersaring buah & & \\
Alat Modifikasi & 8 & \\
Tanpa saring buah & & \\
\hline
\end{tabular}

Hasil kinerja alat modifikasi pembuat MOL menunjukan perbedaan yang signifikan, tampak nyata mampu mempermudah sepuluh kali lebih cepat dalam pengambilan MOL, selama ini pengambilan harus menggunakan alat tambahan seperti saringan dan gayung yang membuat kurang praktis dalam pengambilan dan membutuhkan waktu yang lebih lama. Saat membuka untuk pengambilan MOL tersebut, akan dihirup aroma yang dikeluarkan oleh MOL, membuat kurang nyaman bagi yang sensitiv dengan bau-bauan. Pada alat modifikasi MOL yang tanpa saringan memiliki kinerja lebih lambat dari yang memakai saringan. Hal ini dikarenakan adanya endapan dari bahan baku yang mengisi lubang kran alat tersebut, sehingga sedikit menghambat laju keluarnya MOL tersebut. Pemasangan kran ini diadaptasi dari Alat 
Komposter Cair sebagaiman disampaikan Mr.Farm (2016) yang memasang kran plastik paling bawah ember (terletak di ketinggian $10 \mathrm{~cm}$ dari alas tong) untuk mengeluarkan pupuk cair

\section{KESIMPULAN}

Berdasarkan hasil pengamatan dan pembahasan dapat ditarik kesimpulan antara lain :

1. Alat pembuat MOL yang dimodifikasi tambahan pengaduk, kran dan saringan lebih baik daripada alat pembuat MOL yang biasa dipakai selama praktikum dari segi kualitas MOL.

2. Alat pembuat MOL yang dimodifikasi tambahan pengaduk, kran dan saringan lebih efisiensi waktu dan tenaga serta mudah pengoperasian saat memanen MOL.

\section{SARAN}

Disarankan untuk pembuat MOL dengan modifikasi pengaduk, kran dan pemakaian saringan untuk diterapkan pada praktikum di mata kuliah dengan topik Pembuatan MOL.

\section{Daftar Pustaka}

Farida. 2009. Pemanfaatan Limbah Buah dalam Pembuatan MOL dengan Variasi Jenis Kemasan dan lama Fermentasi. Skripsi Jurusan THP. Universitas Syiah Kuala.

Hadisuwito, S. 2012. Membuat Pupuk Organik Cair. Jakarta: PT Agro Media Pustaka.

Juanda, Irfan, \& Nurdiana, 2011. Pengaruh Metode dan Lama Fermentasi terhadap Mutu MOL (Mikroorganisme Lokal), J. Floratek, 6, 140-143.

Mulyono, 2015. Membuat Mol dan Kompos dari Sampah Rumah Tangga. Jakarta:

PT AgroMedia Pustaka

Palupi. N., Puspita. 2015. Ragam

Mikroorganisme Lokal Sebagai
Dekomposter Ruput Gajah
(Pennisetum purpureum), Ziraa'ah, 40, 123-
128.

Trubus, 2012. Mikroba Juru Masak Tanaman. Depok: PT Trubus Swadaya. 